TURIZAM

Volume 20, Issue 4

192-211 (2016)

ORIGINAL

SCIENTIFIC PAPER

\title{
Historical Review of the Tourism Development of Lake Velence
}

\author{
Wirth Gábor ${ }^{A}$ \\ Received: January 2016 | Accepted: November 2016 \\ DOI: 10.18421/TRZ20.04-03
}

\begin{abstract}
Nowadays the development and future of the well-known Hungarian bathing resort, Lake Velence, have been put to focus by professionals and the media since "Historia est magistra vitae". Even experts must learn from the mistakes and successes of the past. This study is trying to show the tourism development of Lake Velence by analyzing this settlement's functions. Literature, statistics and research deal with this issue. These sources cover actual questions as for the tourism development of Lake Velence. Historical databases of Hungarian Central Statistical Office (KSH) and System of Settlement Data (TeIR) have been used as well as the sketchmap of Geomarket software, which gives a chronological contrast.

The advantageous transport-geographical state and the nearness of Budapest influenced the tourism development of Lake Velence. The development of tourist attractions, primary and secondary suprastructure deepened the differences between the examined settlements. Improvements can be achieved only if a complex regional development is put through in the area of Lake Velence.
\end{abstract}

Keywords: Tourism development, settlement development, functions of settlements, Lake Velence.

\section{Introduction}

The proper mapping of a certain area to be developed, or the lack of this mapping, can determine the results of a whole development project. For this reason it is essential to examine the function and state of a given settlement from a chronological point of view - not only from the area's spatial features. This chronological analysis should be carried out even in the early phase of development projects (Pupos, 2007).

„In Hungary, summer water recreation is the most important type of leisure tourism (beside visiting friends and relatives)" (Formadi, et al., 2017, 223).

Experts dealing with development have to face big challenges due to the position of Lake Velence, because it is situated within different areas of character (the Bakony hills, Mezőföld,

A Enyedi György Doctoral School of Regional Sciences, Szent István University, Páter Károly utca 1, 2100 Gödöllő, Hungary, gaborwirth@yahoo.de 
and Budapest). These challenges cover the fact that Budapest and Lake Balaton are relatively close, and also the main railway line and motorway that run in this area have advantages on one hand, but on the other hand they cause an unbalanced competitive situation. From the economic development point of view of the region, the nearby Székesfehérvár also plays an important role with its industrial centre character. Lake Velence is situated at the northern border of Mezőföld, between Budapest and a chief town of a country Fejér, Székesfehérvár, at the foot of the Velence Hills, $90 \mathrm{~km}$ from Lake Balaton and $50 \mathrm{~km}$ from Budapest. The Lake is also called as "the Lake of Sunshine”, because the number of sunny hours can reach 2050 annually, the temperature of the lake can be $26^{\circ} \mathrm{C}$ in summertime. The whole area of Lake Velence is $26 \mathrm{~km}^{2}$, the open water area is $16 \mathrm{~km}^{2}$, and the reeds take $10 \mathrm{~km}^{2}$ with stable and moving reed islands (Vitek, 2009).

One of this study's aims is to summarize and give a review of the different documents of this area's tourism development. With the help of these an insight is given into not only the history and function change of the settlements of Lake Velence, but also an overview is provided of the ideas for local tourism development, their effects and practical results in a chronological order. This paper about Lake Velence's tourism development is going to fill in a gap in the field of interdisciplinary examination not having been discussed in any monograph or publication yet. When examining the history of this area there arise many still existing problems. The specialist literature does not speak much about the tourism development of the Lake Velence area. This paper's aim is to widen the scope.

Dr. István Polgár wrote the first study (Polgár, 1914) about the economic possibilities of Lake Velence. His work discusses the bathing, the water of the lake and its medical mud.

Votisky (1934) gave attention to the problems of Lake Velence, he studied the water quality, transport, accommodation, touristic role of the settlements, programmes and possible target groups. He analyzed shortly the relationship between Budapest and Lake Velence. Sédi (1944) researched the geographical and economical characteristics of this area. Szauer (1964) introduces in his work the development of Hungarian campings.

The tourism functions and the role of the settlement network in this region have already been discussed in comprehensive analyses (Beluszky, 2003; Beluszky-Sikos, 2007; Aubert, 2011). The settlements Gárdony, Pákozd, Velence and Kápolnásnyék have been analyzed in different monographs (Vitek, 2009; Erdős, et al., 2001; Kupi, 2004; Kupi, 200o) and we can learn about the utilization and change of the lakeside from Boromisza (2012). Tamáska's research (2006) shows the relationship of the built-up environment and the local societies in Sukoró. The wine production of Lake Velence has always been an important part of the local economy (Ambrus, et al. 2005). Nagy (2012) investigates in the topic of the reputation of Lake Velence among locals and the inhabitants of Budapest, as well as people in the agglomeration. However, tourism attractions and the development of primary and secondary suprastructure cannot solve the problems of settlements alone. Moreover, it can even deepen them, so improvements can be achieved only if a complex regional development is put through in the examined areas.

The tourism of Lake Velence, even though significant developments, was not able to break down its geographical barriers: the advantageous transport-geographical state and the nearness of Budapest determined the role of this tourism destination. 


\section{Methods and Data}

Investigating into the specialist literature is an essential starting point of the research of the examined region. Besides monographs and related literature of the settlements of Lake Velence, many contemporary regional development documents have been analyzed. The results of the Hungarian Central Statistics Office and the System of Settlement Data's (TeIR) historical database have been combined with the help of Geomarket software to show map representations. This method helps to compare results in a chronological order.

The examination of the tourism development of Lake Velence should be started from the beginnings of the bathing culture of the Lake, from the 1910s, for before that time the settlements in this region used to have merely agricultural functions. The present examination covers only those settlements around Lake Velence which had apparent tourism functions shown by SSD (TeIR) and the Hungarian Central Statistics Office. These data are derived from the number of commercial, private and social accommodation, the number of guests and guestnights. This analysis deals with Gárdony, Kápolnásnyék, Nadap, Pákozd, Pázmánd, Sukoró and Velence. The temporal changes of the region's economic functions can show the size and success of tourism development. This is intended to prove with the examination of tourism infraand suprastructure changes.

\section{The beginnings of the bathing culture of Lake Velence in the 2oth century}

Despite the fact that the Lake had already been a favourite bathing destination of several people from Budapest since 1907-1908 (Polgár, 1914), the main activities here were fishing and sedge-cutting. The shire reeve, Miklós Jankovich, also dealt with sedge-cutting and selling. However, the locally produced sedge was suitable only for domestic markets, not for exports, because it was softer than the sedge grown at Lake Fertő.

Dr. István Polgár's work „Lake Velence” (A Velencei-tó) discusses the economic possibilities of the Lake, paying a high attention to the alternatives of the water of the Lake and its medicinal mud (Polgár, 1914). Freetime was an important requirement of holiday and the development of tourism at the beginning of the 2oth century. This was introduced by the Bethlen government in its 1923 Act, and it covered the wider strata of the society. The Act introduced the 8-hour working day and the payed holiday (Kupi, 2004). Polgár imagined the development of railway from Budapest to Lake Velence in a way that „we would build two junctions for the tram, one to Velencze, the other through Kisvelencze as far as Gárdony” (Polgár, 1914, 39).

The different characteristics between Lake Balaton and Lake Velence were salient, as Polgár claims "there is no need for luxury, the one who needs it can carry on to Lake Balaton” (Polgár, 1914, 34). Besides the railway, water transport should be realized between the settlements of the Lake. The transport between the northern and southern shore should be ensured with building harbours on condition that petrol-driven motorboats are purchased by the holiday resorts in the area to make connections with the Sukoró shore because "Sukoró is perfectly protected from cold winds and is open to the warm stream from the south. For this reason it is an ideal holiday resort and sanatorium" (Polgár, 1914, 39).

The reconstruction of the neglected Gárdony shore started in the 1920 and wealthy Budapest dwellers started to purchase plots at Lake Velence. Locals quickly recognized the possibilities of tourism here: they established the Bathing Deposit Association (Fürdő Betéti Társaság) to inform and serve bathers and nature lovers. From the 1930s this Association was headed by 
Béla Laczkovics, a Székesfehérvár restaurant owner (Vitek, 2009). The establishment of the public beach and the catering units shows the successful activity of the Association. The first accommodation connected to bathing was the Sirály Inn with 13 guestrooms, led by Gyula Bóné, who phased winegrowing in Gárdony. The Gárdony beach operated in its today's site, near the railway station. A children's playground, a carpark and cabins belonged to it. The Gárdony Boat-renting Company provided sailing and rowing possibilities for visitors (Vitek, 2009).

The holiday resorts of the southern shore were connected to the Budapest-Balaton road transport with a road through Kápolnásnyék, Kis-Velence, Gárdony, Agárd and Dinnyés. The northern shore could be approached by the old road through Pákozd, Sukoró, and Velence (Erdős, et al., 2001).

According to the Archives of Fejér County the Gárdony bathing resort was very popular even in the 1930s: „The public has been visiting Gárdony in growing numbers and uses it for bathing because of the healing effects of the water of Lake Velence. It is quite common that thousands of visitors spend a day there" (AFC, 1930).

After the Nádasdy estate had been shattered and sold, the Agárd bathing resort was born at the beginning of the 1930s. At that time many holiday homes were built. The Balaton road was built by 1936, the year when Agárd was declared to be a bathing town. Also the Agárd petrol station was opened and the public utility services were widened. According to the specialist literature, 280o guests spent more than a month in the settlement in 1936.

In 1930, 8463 people lived in the four lakeside settlements, 2830 in Pákozd, 2603 in Velence, 2140 in Gárdony and 890 in Sukoró. The average population number of Fejér County was reached only by Velence, the other settlements were scarcely populated. More than three-quarter of the population are primary producers, farmers. Half of the population of the lakeside settlements live in the outskirts (Sédi, 1944).

Between the World Wars a lot of civil associations were formed to strengthen national identity. Two of them, the Gárdony Bathing Association (1930) and the Agárd Bathing Association (1933) have to be highlighted. The Gárdony Bathing Association, led by Count Viktor Széchenyi, had two headquarters: in the bathing season in Gárdony, in the shoulder season in Budapest. The aims in the fundamental rules included „the development of Gárdony bathing resort", ensuring the standards of the public health service, the representation of locals and visitors of the bathing area. At that time the „Sirály (Gull) Beach” and the „Big Beach” waited for people to bathe (Vitek, 2009).

The Agárd Bathing Association set goals to develop the bathing areas and widen the range of services besides the representation of its members. Also, they tried to back "all institutions and activities related to Lake Velence". They wanted "to guard houses empty in the wintertime” (Vitek, 2009, 148). The seasonal feature of Gárdony and Agárd was an important fact even in the first half of the 2oth century, so seasonality of the Lake is not a present-day problem.

The relationship of Agárd and Gárdony in terms of functions was interesting: the majority of the holiday resort belonged to Agárd, however, Gárdony became the center of the holiday area. The reason of this is the Gárdony Market, which was very popular with locals, and also the commercial units opened here (Vitek, 2009).

According to Antal Votisky, 95\% of those who bought weekend lots are from the capital, and in 1934150 ooo visitors arrived here by train, car or bicycle. These visitors were the weekend house and lot owners, their family members and guests, summer holidaymakers and mostly weekenders. „80 \% of the 150 ooo visitors are mostly from Budapest” (Votisky, 1943, 24). Professor Jenő Cholnoky's statement about Lake Velence correlates with these data. At the Velence Lake National Convention he claimed that Lake Velence „is not the competitor of Lake Balaton, 
they supplement each other in tourism." He says that Lake Balaton is suitable rather for longer stays and holidays, and Lake Velence, due to its closeness to the capital and cheap accessibility, is preferred by weekenders and is popular among people who prefer cheap and short time bathing. As for Jenő Cholnoky, Hungarian-style weekend houses and cottages should characterize the environment of Lake Velence (HNR, 1936).

Antal Votisky has a separate chapter in his work dealing with the problems and their solutions of Lake Velence, analyzing the relationship of Lake Velence and Budapest. In 1934 Votisky had exact views of the future of the settlements of Lake Velence: „if MÁV (Hungarian Railway Company) introduces the Árpád-system fast engine, Lake Velence will become Budapest's outskirts because of the increasing number of inhabitants. Lake Velence will not be a bigger excursion problem than today Csillaghegy, Békásmegyer or the Hármashatár-hegy, even Zugliget or Máriaremete" (Votisky, 1934, 25). In Votisky's statement there are two important facts: railway transport has a definite role in the future of the northern shore settlements, and these areas can become the agglomeration of Budapest, partly because of migration. During the activities of the Velence Lake Syndicate, their 1934 publication provided ideas not only for experts engaged in the development of the Lake and its settlements, but also a great number of principles and statements can be found in this document which can form the basis of the latest regional development concepts. The paper was reprinted in October, 1975.

In Votisky's work there is another element regarding the future: the establishment of a social body, which is concerned about the development of Lake Velence. He called this body Lake Velence National Association (Velence-tavi Országos Szövetség, VETOSZ). The changes of the southern shore, the birth of tourism and bathing culture and their development had an impact on the life of the northern settlements. The Buda road through Pákozd was regularly maintained, and the settlement entered into the Lake Velence National Association. As a result, current supply was installed as well as street-lighting and a year later the new local government building was built. The next step of development was the building of the surgery and flats (Erdős, et al., 2001).

From the 1930s the economy development plans put bigger and bigger emphasis on the development of tourism and the shore. At this time the economic function of the Lake completely changed: the importance of sedge production, wing-game hunting and fishing started decreasing due to the emerging bathing culture (Erdős, et al., 2001). The long-existing latifundiums were the reason why the Agárd and Gárdony shore was allotted as a bathing area only in the 1930s. The new Balaton road was built around this time too, which was an important part of the bathing infrastructure. Then it was a governmental aim to improve the water quality and the road system.

In the first decades of the 2oth century the holiday resorts of Lake Velence developed by themselves and rather uncontrolled because the 1911 Act - which was still in operation - did not deal with the requirements of a modern resort or bath. Consequently, unsuitable plot distribution and non-aesthetic, incendiary, and scenery non-fitting buildings were not rare on the shore. To solve this problem, the leadership of Fejér county tried to introduce a more modern plot distribution act. For this the Gárdony Bathing Association was responsible (Votisky, 1934).

In the 1930 s Lake Velence visitors were Budapest bathers, tourists from all over the country and from the ceded areas, and also locals (Votisky, 1934).

The Hungarian Royal Central Statistics Company carried out an analysis about Hungary's bathing and holiday resorts in 1938. This paper confirms that at that time "the officially acknowledged and registered number of resorts is ... few" (HSI, 1938, 10). Most of these resorts are at Lake Balaton. At Lake Velence, Gárdony, Agárd and Velence were registered holiday 
resorts. From the development point of view it is important to note that the Balaton resorts belonged to the Balaton Syndicate, Lake Velence's resorts belonged to the Lake Velence Association, the other settlements belonged to the National Tourism Association. According to the 1937 statistics, Gárdony had 2, Agárd had 1, and Velence had 1 beaches. The numbers of hotels, pensions, inns - which form the primary elements of tourism suprastructure - are 4 in Gárdony, 2 in Agárd and 4 in Velence. As for bed numbers it is 33, 17 and 46 (HSI, 1938). Consequently, both settlements could be preferred resorts.

Table 1. Comparison of settlements at Lake Velence and the most important tourism centers at Lake Balaton in terms of the number of hotels, pensions, inns and beds in 1937.

\begin{tabular}{|l|c|c|}
\hline Name of settlement & Number of hotels, pensions and inns & Bed number \\
\hline Gárdony & 4 & 33 \\
\hline Agárd & 2 & 17 \\
\hline Velence & 4 & 46 \\
\hline Pákozd & 2 & 9 \\
\hline Kápolnásnyék & 4 & 14 \\
\hline Balatonfüred & 15 & 593 \\
\hline Balatonalmádi & 27 & 638 \\
\hline Balatonboglár & 16 & 604 \\
\hline Siófok & 37 & 1228 \\
\hline Balatonlelle & 28 & 776 \\
\hline Keszthely & 14 & 213 \\
\hline
\end{tabular}

Source: private editing based on the data of HSI, 1938

The owners of non-paying week-end houses and cottages provided accommodation in bigger numbers than hotels, pensions and inns. Tourists could find hotels (pensions and inns) in Gárdony, Agárd, Velence, Pákozd and Kápolnásnyék. However, in this category the settlements of Lake Velence could not compete with Lake Balaton's main tourism destinations (Table 1).

As the year of 1937 data show, before World War II, Gárdony, Agárd, Velence, Pákozd and Kápolnásnyék had tourism functions. Despite the rare number of accommodation, the transport system was quite modern compared to the country's other resorts: the two most important settlements of the Lake, Gárdony and Velence both had a railway and coach station. Gárdony had a petrol station and Velence had a garage (HSI, 1938).

In the 1930 s thousands of people visited Lake Velence but at that time the primary tourism suprastructure was not satisfying, the accommodation and catering possibilities could not fulfill the increasing needs. For this reason ,the inhabitants of the lakeside settlements let out one or two rooms for hotels from Spring to Autumn, for charge" (Votisky, 1934, 18). Providing the different category accommodation was the basis of the tourism development of Lake Velence, the number of guests could increase.

Besides the increasing popularity of Lake Velence, it was an important issue to deal with the tourism problems of the area. As seen from Sédi's balneological map (Figure 1), most of the lake was covered with reeds, open water could be reached by visitors only on the Agárd and Gárdony shore and also on a small area near Velence. Around Agárd and Gárdony the lots were adjusted to the easily approachable open water.

In the 1930 s the shore was not regulated, the cleansing of the bed of the lake and the building of big capacity modern hotels were on hold because of the lack of conduits, gutters and 


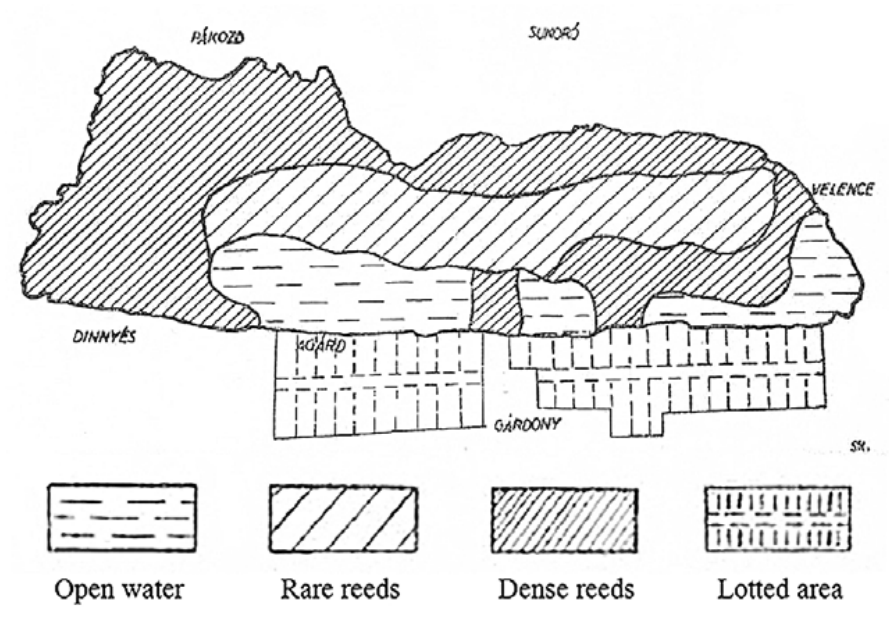

Figure 1. The balneological map of Lake Velence. Source: Sédi 1944

shore management. Current supply was available only in the one-third of the Lake Velence area. For these reasons (wealthy) foreign tourists visited the Lake only to hunt for aquatic birds, to do fishing and yachting.

\section{Tourism development of the settlements at Lake Velence after World War II.}

After World War II, in the 1950s, the regional and settlement development was reduced to maintain the beaches and the bathing culture as well as to smaller investments. The turning point was when the Fejér County Council Executive Committe, in its 8 January, 1958 Measure decided to set up The Lake Velence Managing Committee, which was responsible for the development of the lakeside. President Dr. Gyula Dabrónaki and Secretary General Dr. Ferenc Springer coordinated the development project. Dr. Ferenc Springer's name should be highlighted because he made a lot of efforts to save Lake Velence and to build up the shore. By 1960 more than half of the Lake was covered with sedges, so the most important result of the Committee was to save the Lake (Erdős, et al., 2001). The Zámoly and Pátka reservoirs could maintain the water level, and by cleansing the bed of the lake, 6 million m3 mud was removed by 1980 .

Shore protectors, piers and harbours were established and this formed the basis not only of camping and bathing tourism but also it had changed the view of the shore. The role of the Lake's settlement system became determining from that time.

The socialist decision makers were driven by Bulgaria's successes in joining international tourism. They wanted to use this for propaganda goals, so the developments in tourism were to popularize the socialist system (Rehák, 2011). The development of our national and international tourism was to be carried out by private accommodation services and state controlled camping possibilities because these novelties required the least investment and their realization was quick (Záhonyi, 1964).

In 1964 the VIB (Lake Velence Managing Committee) established the Agárd campsite, which could receive 300 guests. This campsite was the most organized of all the other lakeside camping sites. Besides camping, the site had 20 concrete weekend houses for more conveni- 
ence. It was essential to create the proper technical infrastructure too: water supply and public lighting in the whole territory of the camp, showers for men and women, caretaker's office with telephone and television, covered common room, basket- and volleyball court, and the local beach waited for the guests to relax. The public transport facilities also contributed a lot to the development of tourism: the camping was easy to access from the No 7 Balaton motorway and from the Agárd railway station (Szauer, 1964).

At this time higher category accommodation types were also available besides the dynamically developing campsites. At the Lake, in 1965, the Agárd Hotel Varsa and also here, in Gárdony, the Gárdonyi Géza Hotel operated with 18 and 20 beds, which meant 5 and 8 rooms. A little further from the Lake, in Nadap, the Meleg hill offered a tourist lodge with 4 rooms, for 50 persons. The year of 1965 data show that Nadap already had some tourism function, which was probably because its natural attractions. In 1965 1304, in 19661393 guests stayed here for the night, out of which the foreign guests were 100 in 1965 and this number doubled by 1966 to 209 visitors (HCSO, 1967).

The number of shops in the settlements could fulfill the needs of neither tourists nor locals: „In the smaller settlements there are only foodshops or stores, for more important shopping inhabitants travel to bigger villages or to towns" (Boór, 1970, 64).

The Budapest-Székesfehérvár part of the M7 motorway was opened in 1968 and this had a positive effect on the tourism of Lake Velence besides on Lake Balaton (Boór, 1970).

The general plans of Lake Velence and its settlements were finalized by 1963. In this document Gárdony, Velence, Sukoró, Pákozd, Kápolnásnyék and Nadap were included. Later this regional development plan was enlarged with Vereb, Pázmánd, Pátka and Lovasberény. From the 1970s it was clear for the bodies dealing with settlement and regional development that „the Lake Velence area is one unit mostly because of its tourism function. Tourism, within this domestic tourism generates the development of this region" (AFC, 1971). Supplementary regional development covers forestry, agriculture and industry.

Tourism development results marked the 1960s. There was a strong boom in the number of inhabitants in Gárdony in 1970. „The number of holidaymakers and excursionists is increasing fast. Last year (1969) 300-320,00o visitors stayed here in factory cottages, weekend houses, campsites and guest houses" (Boór, 1970, 93).

To relief Lake Balaton, Lake Velence area had to be improved, and it was important to make use of the Lake's favourable energies: „Due to the increasing freetime, the Lake has an important role, which is accelerated by its advantageous geographical position" (AFC, 1971).

As a result of the 1971 development concept, new public buildings and commercial units were built: the Gárdony local government building, the Hall of Waterworks, the Lake Association, OTP Bank branches, bookshops, the new Velence store, the ÉDÁSZ outlet, the special education school and an elementary school were erected. At this time the lack of green areas meant the biggest problem in settlement development here.

The Lake's $120 \mathrm{~cm}$ surface level change was reduced to $20 \mathrm{~cm}$, thanks to the 1971 Lake Velence Development Programme. This result was completed with the Dinnyés-Kajtor canal and with the new Zámoly and Pátka reservoirs.

In 1974 Lake Velence was declared to be a fishing lake and intensive fishing was banned (Erdős, et al., 2001).

In the 1970 and 1980 s many $\mathrm{ABC}$ foodshops, stores and groceries were opened, however markets were missing as well as non-food category groceries (HRDUP, 1987).

According to VÁTI's research, at the hottest weekend in July, 1977, 2000 people/day by bus, 6000 people/day by train, 16900 people/day by car, altogether 24900 people/day visited the 
Lake. As for the annual data, the weekend traffic exceeded the number of accommodation, so besides 21600 holiday beds 22 ooo people/day visited the Lake and its surroundings in case of good weather (HRDUP, 1980). However, the changes in travel habits do not mean the need of raising accommodation capacity because people visiting the Lake did not want to stay for the night, they were only one-day beach visitors. VÁTI did not survey the exact target niche, the travel and staying habits of guests, so this question cannot be answered fully. VÁTI tried to calculate the number of holidaymakers from the amount of season tickets. This number was 3350 in 1976 and 4780 in 1977 (HRDUP, 1980). The number of season ticket holders refers to the number of the Lake's regular visitors, however the number of permanent holiday makers is uncertain because locals could have season tickets as well.

The most important hotel in 1977 was the Agárd Touring Hotel, with 157 beds. The hotel capacity was planned to be widened to 1650 beds. Building company cottages had two aims: besides summer holidays they hosted courses and conferences in winter (HRDUP, 1980). Despite Lake Velence's considerable weekend turnover, it had only 0,1\% of the country's guest nights in 1978, and without private accommodation this number was $0,4 \%$ (HRDUP, 1980).

The 5019/1979 Act of the National Plan Committee (Állami Tervbizottság, ÁTB) posed the basic principles of Hungarian long-term tourism development. It included the establishment of campsites in Lake Velence-Vértes resorts, developing thermal tourism and the most important holiday resorts, increasing the role of paying guest services and widening organized tourism in the field of cultural-, entertainment- and sports facilities and services.

Examining the Lake Velence-Vértes region it is an important relation that within the background settlements of the Lake, its influence can be felt only in the southern shore villages. This can be seen from the data of labour market: in most cases young adults took up jobs in tourism.

In the 1980 os, tourism development activities were carried out on the basis of attractive values, and the technical, economic and regional terms of tourism had to be ensured. The market of Lake Velence was „basically the inhabitants of Budapest and Székesfehérvár”.

Due to he closeness of Budapest and the cheap allotment prices, mostly pensioners, civil servants and workers, the „men-in-the street” purchased lakeside houses here (Huba, 1966).

The Ministerial Council had examined the successes of Lake Velence Central Development Program (confirmed in 1971) in 1985, and it aimed at a new long-term development project till 2000 (resolution 2014/1985. MT/VI.11.). According to this resolution „the Lake Velence region is a national value of special protection" (HRDUP, 1986, 1), so along with its further development, its natural habitat and holiday resort character have to be maintained, the lake's water quality has to be improved. In the resolution the successful results regarding the bathing and watersports facilities are highlighted. At the same time, in 1986 VÁTI claimed that „tourism has increased faster and in bigger amount at the Lake than planned" (HRDUP, 1986, 22). The more than expected dynamic weekend and beach turnover also contributed to this fact. The number of private weekend houses also exceeded the limit in 1986.

The number of accommodation in Velence-Vértes resort shows a dynamic increase in all the three categories, the biggest change refers to the number of commercial accommodation types (hotels, motels, campsites, paying guest services) (Table 2). Efforts made in social tourism are also worth to mention, in the period examined many youth and holiday camps were built. Despite this fact, private cottages were in bigger numbers. According to the Hungarian Regional Development and Urban Planning Non-profit Association, the average stay in this period is relatively short: in 1974 it is 3.4 , in 1985 it is 3.8 days. 
Table 2. Changes in number of accommodation in Lake Velence-Vértes resort between 1971 and 1985

\begin{tabular}{|l|c|c|c|}
\hline & 1971 & 1985 & $1971 / 1985$ \\
\hline Commercial accommodation & 555 & 5311 & 9,56 \\
\hline Company accomodation & 842 & 2947 & 3,5 \\
\hline Private weekend house accomodation (cottages etc.) & 14170 & 28300 & 2 \\
\hline Total & 15567 & 36558 & 2,35 \\
\hline
\end{tabular}

Source: HRDUP 1987

In 1983-84 in the main season at Lake Velence there are about 120 ooo bathers at weekends, the paying beaches are visited by about 56 ooo people. The beach capacity is 55400 , so in the peak times at weekends the beach facilities, such as toilettes, changing rooms and other services cannot satisfy the visitors' needs (HRDUP, 1987).

These problems can be derived from the fact that the aimed $17 \mathrm{~km}$ long new beach in 1971 was built only in $4.8 \mathrm{kms}$ till 1985 , due to lack of financial subsidies. The Hungarian Regional Development and Urban Planning Non-profit Association claims that The Lake Velence Common Financial Firm managed the beaches at Lake Velence unprofitably (HRDUP, 1987). The problem of maintenance in the settlements of the Lake lies in the connection between their functions. In 1984 Gárdony got the town rank, but the town did not fulfill its role, it had little influence on its background settlements and the transport system between them was unsatisfactory. Arranging official matters and shopping were problematic in these settlements. Food commerce could fulfill the needs of customers only in the shoulder seasons, and in parallel with it many people did major shopping in Székesfehérvár. The background settlements of Vértes resort had no, or just little holiday function, so the number of customers at weekends and seasonality did not cause problems there unlike in the other resorts of the Lake.

The public transport problems of the background settlements were dealt with already in 1985. The rare Volán buses made movements difficult in the region in 1980, and at weekends motorists had to face with only few parking places (HRDUP, 1987).

The influence of Budapest can be seen from VÁTI's „The regional development plan of Lake Velence resorts” paper: Gárdony, Velence, Kápolnásnyék, Sukoró and Pákozd were referred to as "area of agglomeration” (HRDUP, 1986).

The northern shore was behind the southern comparing it with infrastructure and supply, here even locals' needs could not be satisfied. In 1986 running water was missing because it was full of nitrate and the polluted water was not suitable for drinking. Water supply was completed with watertank cars. The 1986 regional development plan of Lake Velence resorts proposes "less built-up areas than in the previous plans" on the northern shore, which meant 5-60oo holiday beds instead of 21000 on the shore of Szúnyog island and the rowing area. Cheaper and lower category accommodation types and campsites were to develop, as for the typical tendencies of tourism in the 1980 os (HRDUP, 1986). The number of more expensive, higher category accommodation types shows an interesting picture: from 1970, within 10 years, in Gárdony the 180 hotel beds were increased to 432 by 1980 and it decreased to 404 beds in 1985 . In Velence the hotel bed number increased only by 1 between 1970 and 1980, and this remained the same in 1985 (SSD). The higher needs could not, and was not intended to be fulfilled at Lake Velence because campsites and lower category accommodation types were cheaper to maintain and rent.

Experts dealt with the idea of the relief of Lake Balaton due to the location of the settlements at Lake Velence between Budapest and Lake Balaton. However, besides the proper infra- 
structure, the tourism infra- and suprastructure were not satisfactory on the southern shore of the Lake. The tourism infrastructure was incomplete because of the limited number of beach spaces and their facilities. The accommodation types of primary suprastructure were limited to campsites and lower category accommodation. Catering development provides an interesting view (Table 3 ).

The changes of areas of catering units show a dynamic development from 1970 to 1985 in Gárdony and Velence. However, we can see a decreasing tendency from 1985 to 1990. Kápol-

Table 3. Changes in the area of catering units in the settlements of Lake Velence

\begin{tabular}{|l|c|c|c|c|c|c|c|}
\hline $\begin{array}{l}\text { Area of restaurants, } \\
\text { catering units }\left(\mathrm{m}^{2}\right)\end{array}$ & Gárdony & Kápol-násnyék & Nadap & Pákozd & Pázmánd & Sukoró & Velence \\
\hline 1970 & 2897 & 898 & 95 & 641 & 233 & 87 & 1965 \\
\hline 1980 & 4117 & 819 & 93 & 469 & 233 & 89 & 3160 \\
\hline 1985 & 6307 & 805 & 93 & 469 & 233 & 101 & 7389 \\
\hline 1990 & 5002 & 884 & 93 & 920 & 180 & 105 & 2126 \\
\hline
\end{tabular}

Source: private editing by SSD data (www.teir.hu)

násnyék, Pákozd and Sukoró show development in this field again. If we compare the data of the catering unit areas with the number of accommodation, we can observe that in the year of 1990 in Gárdony 14 and in Velence 10 catering units closed down. Within the settlements of less tourism function it is only Pázmánd that lost one catering unit by 1990.

As for the number of guests at tourism accommodation, it increased in Gárdony from 30,527 to 45,483 , if we look at the years of 1980 and 1985 . This increase is even higher in Velence: it means guest number growth from 1149 to 28,777 . The customer number of retailers grew from 250,807 to 400920 in Gárdony in 1980 and 1985. This number in Velence is from 132,082 to 298,264 .

Table 4. Changes in the area of retailer shops in the settlements of Lake Velence

\begin{tabular}{|l|c|c|c|c|c|c|c|}
\hline $\begin{array}{l}\text { Area of retailer } \\
\text { shops }\left(\mathbf{m}^{2}\right)\end{array}$ & Gárdony & Kápol-násnyék & Nadap & Pákozd & Pázmánd & Sukoró & Velence \\
\hline 1970 & 1982 & 1509 & 113 & 669 & 308 & 170 & 856 \\
\hline 1980 & 3353 & 1659 & 113 & 482 & 201 & 195 & 1856 \\
\hline 1985 & 3660 & 1951 & 113 & 615 & 360 & 179 & 934 \\
\hline 1990 & 3192 & 1882 & 113 & 461 & 360 & 169 & 1454 \\
\hline
\end{tabular}

Source: private editing by SSD data (www.teir.hu)

In case of Gárdony and Kápolnásnyék the area of retailer shops dynamically increases from 1970 to 1985 , but it decreases in 1990 (Table 4). The period of 1970-1980 is positive, and the data of 1990 are remarkable. The fact that Kápolnásnyék and Velence were practically one area in 1985, it balances the drastic decrease in 1985 . The area of retailer shops shows a relatively steady rate in Nadap and Pázmánd as well as in Sukoró on the northern shore.

As seen from the above, there is a close relationship between the change of tourism accommodation, catering units and retailer shops. Investments in the tourism industry have a positive impact on the whole of the local economy.

If we compare the census data of the years 1960 and 1980 on the grounds of the active population, we can have a view of the changes in the region's economic structure (Figure 2). 

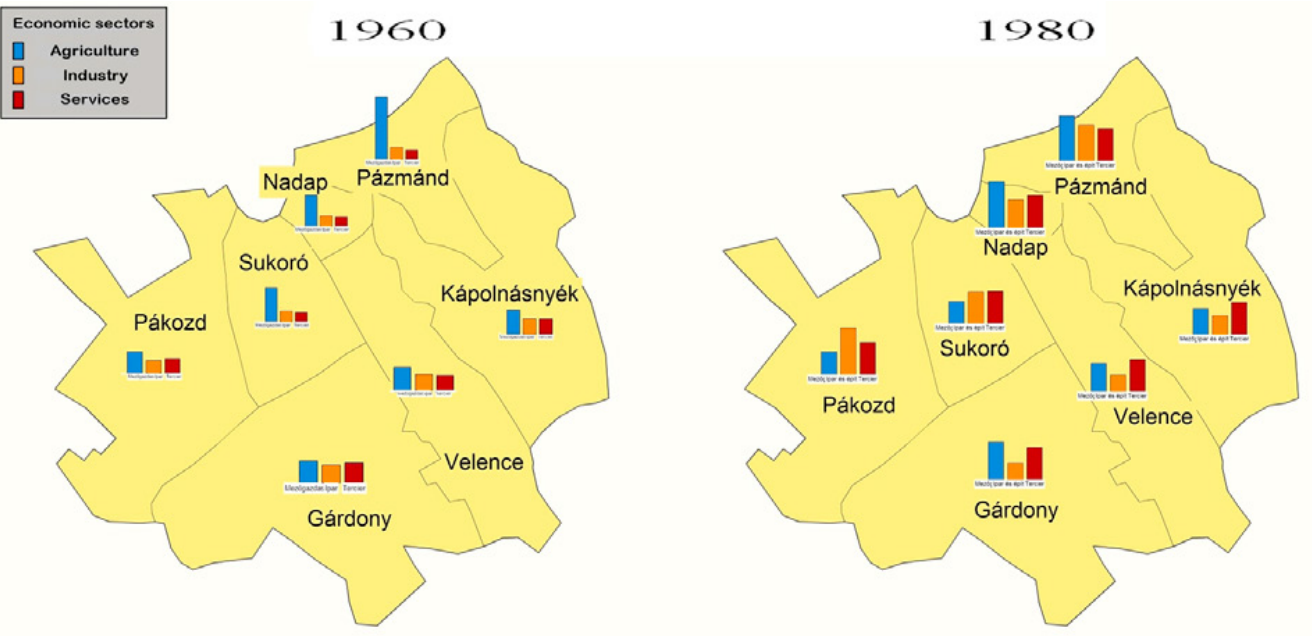

Figure 2. Changes in the number of the active population in the settlements of Lake Velence according to the 1960 and 1980 census

Data source: Private editing with Geomarket Software by SSD data (www.teir.hu)

We can see that agricultural function dominates the settlements of Lake Velence in 1960. By the map we can state that the farther a given settlement is from the Lake, the stronger its agricultural function is. In 1980 the number of industrial workers is growing and agriculture loses its importance in all settlements and the tertiary sector is gradually increasing. At that time in Velence with its important tourism role, Sukoró on the northern shore, and in Kápolnásnyék, which was the commercial center of the region, the active population was employed in the tertiary sector. In the most populated settlement it was interesting to see the distribution of the active population in each sector. In 1980, in Gárdony most of the people worked in the agriculture and in the tertiary sector. This fact has many reasons. The relatively balanced results are given from the mutual data of Gárdony and Zichyúffalu in case of Gárdony. The settlement, south of Gárdony, became an independent village only at the end of the 2oth century, in 1997. It was connected to Gárdony in 1962 because nearly 8o \% of the population here worked for the Agárd Victory State Company (later Agárd-Zichyújfalu Agricultural Company). Besides, many people commuted to Székesfehérvár. It is important to note that the then large village-ranked Gárdony consisted of more settlements: Dinnyés, with its village character, Agárd, the favourite bathing town, and Gárdony, the center of administration. Also, Zichyújfalu, with its village feature, was part of Gárdony. The public transport infrastructure, the No 7 motorway and the Székesfehérvár-Budapest railway provided opportunities to take up work in other towns, among others in Székesfehérvár and Budapest. As the 1971 Lake Velence Central Development Programme stated, industrial activities were not allowed at Lake Velence, so employees working in the secondary sector commuted to other settlements.

The two most important towns, Gárdony and Velence changed their functions as seen in the specialist literature as well: „Trends influencing the development of towns can lead to the change of the operating model, they help to create new town evolution. The functional model change comes into being when a town starts to operate by different principles than before. Such examples are when a new railway or motorway is built, which has a strong impact on the actuation of a settlement. It can reorganize the whole operation of the settlement, it can 
change its area use and settlement structure" (Ruzsányi, 2005, 19). The connection between developments in the infrastructure and tourism can be seen in the specialist literature. Tourism requires the active development of infrastructure, roads, water and electricity supply, garbage removal, and telecommunication. This „can be organized in a way that locals could make use of it and share the advantages of developments" (Lengyel, 2004, 29). The inhabitants at Lake Velence were also users of the developments in the infrastructure.

We have to determine the local target groups, as seen form the development ideas of Lake Velence's general organizational plan. According to this, unlike the previous imaginations, besides the citizens of Budapest and Székesfehérvár, visits from Dunaújváros and abroad are also objectives. The organizational plan determines the level of capacity in the region. According to this, the number of visitors and tourists staying here at the same time is 135000 , the maximum accommodation possibilities are 93 ooo beds, the capacity of beaches is 90 ooo (HRDUP, 1980). The organizational plan dealt with the then existing tourism trends and interdependences. It did not count with the fact that the average staying time can decrease, which means 18160 people per day (HRDUP, 1980). Given that tourists prefer good hygenic conditions, environmental development was also a case at issue. The growing tourism at Lake Velence contributed to the preservation and development of local nature reserves, history, culture and traditions.

\section{Tourism development problems in the 1980s: Influence of the widening tourism function on the settlements of Lake Velence}

Carrying out modern development became quite problematic due to the shrinking financial sources in the second half of the 1980s. However, environmental protection aspects were in focus and it referred to the whole drainage area of the Lake. This meant to deal with a big regional unit. The booming tourism of Lake Velence and the traditionally agricultural settlements were in contrast and it resulted in conflicts. This foil could be settled with new development regulations. The general organizational plan of Lake Velence area says that „tourism has a priority to agriculture in the drainage area of Lake Velence. Every factory against the interest of tourism has to be closed down or forbidden to expand" (HRDUP, 1980, 50). According to plans, the increase of tourism capacity at the Lake could relieve Lake Balaton, and it meant establishing beaches and campsites. The tourism capacity in the region was determined from ecological viewpoints. Even today it seems to be a modern idea to extend tourism with village and thermal tourism, and to involve the background settlements into the programme.

From the 198 os all tourism development concepts dealt with the local energies of Lake Velence: for this region is situated in the busiest tourism area of the country, its connections and relations with Székesfehérvár and Budapest are also parts of analyses.

The 1986 regional organizational plan describes the correlation between infrastructure developments and population growth. The good commuting possibilities to Budapest and Székesfehérvár and the infrastructure - public utilities and the range of services - became attractive to the public and grew the number of settlers.

Travel habits also changed a lot in the 1980 os. Besides weekend beach visits, Lake Velence became the place of half- or one-day excursions due to the closeness of Budapest.

This tendency can originate in the unfavourable economic situation and the higher petrol costs. People preferred destinations that could be reached quicker, cheaper, and were nearer to their homes. As a result, weekend traffic grew much at the Lake and cheaper accommodation 
types were chosen here. The role of Lake Velence grew in terms of recreational habits of Budapest and Székesfehérvár. In the main season about 100 ooo people were at the Lake at the same time and whose arrival and departure were also at the same time so it caused transport and servicing problems (HRDUP, 1980).

It shows the role of Lake Velence in the tourism of Hungary that the village Agárd has been mentioned in the documents of STASI (The Ministry for State Security). They spied on the potential dissidents and other GDR citizens who wanted to meet their relatives and friends from FRG at Lake Velence (BStU, 1986).

Problems of the growing number of beach visits and excursions were typical in the areas of the southern shore and in the Velence bend. These problems were to be solved by creating beaches and holiday areas on the northern shore, expecting to have a three times more beach capacity. The plans included establishing more green and sports areas, which was not possible on the southern shore due to lack of space.

In the 1980 os the extent of tourism was much bigger that expected, so water supply and utilities had to be solved and reconsidered. At that time water shortage was an everyday problem.

The specialist literature discusses the negative effects of the over-dependence of local economy on tourism. This dependence on the tourism sector is highly typical of the Lake Velence region, for the economic structure change shows and direct transition between the agricultural and tourism sectors (Mason, 2003).

\section{Tourism development after 1990}

Suburbanization and the growing importance of tourism have changed the size and structure of the towns at Lake Velence (Tamáska, 2006). The biggest settlement of Lake Velence is Gárdony, which gained the town rank in 1989. Gárdony belongs to those 9 town ranked settlements in Hungary whose "leading and only function is tourism (this is $4.5 \%$ of our towns)" (Beluszky, 2003, 424). The originally agriculturally functioning towns, Gárdony and Agárd, became towns due to tourism. The appearance of tourism reformed not only the face of these towns but also their economical structure. Gárdony, as a holiday resort, is a dynamic element of Hungarian towns, the numb er of entrepreneurs is high here, the number of population is growing, the town's role is gradually more and more important (Beluszky, 2003).

The other significant settlement in Gárdony township is Velence, which was declared to be a town in 2004. To gain this rank, the settlement's tourism function played an important role. The specialist literature claims that Velence has few "town-like” features on the basis of its role in the settlement system and its functions as a town, as well as its visual appearance (Beluszky - Győri, 2006).

The changes in the number of guest nights in the campsites of Gárdony and Velence, comparing it to camping tourism and the role of bathing at Lake Velence have been examined too. The research covers the years between 1990 and 2014, i.e. 25 years' data (Figure 3). The campsites of Gárdony (with a town rank from 1989) and Velence had a decreasing number of guest nights from 1990 to 2012.

The year of 2008 hit the bottom due to the beginning of the economic crisis, but later a slow increase can be followed.

The data of the Gárdony's and Velence's campsites show a definite downturn in camping tourism from 1990. A number of reasons could explain the decline in camping tourism in the past decades: the development of transport and the changes in travel habits resulted in short- 


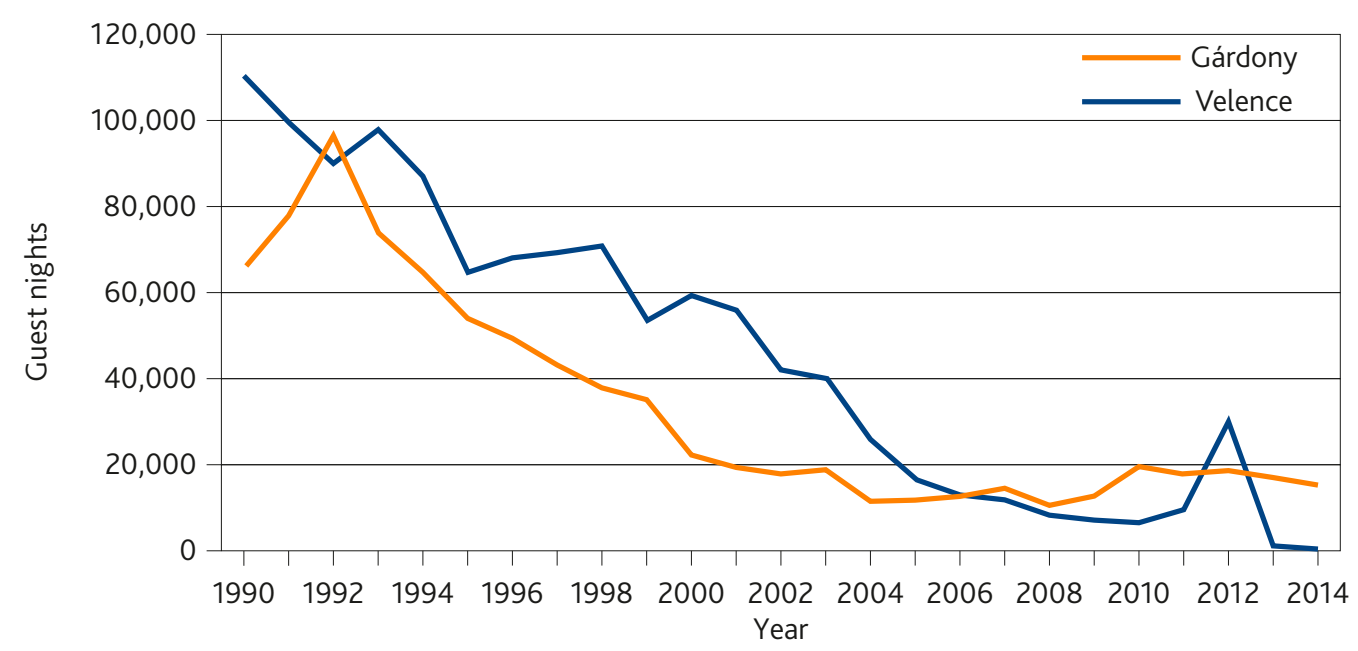

Figure 3: The guest nights of the campsites of Gárdony and Velence from 1990 to 2014 Source: private editing by SSD data (www.teir.hu)

er stays in the resorts, the accommodation offers widened so it was possible to stay at higher category but still affordable hotels. Parallel to the decrease in camping tourism, the Lake Velence area started to offer a wider range of freetime programmes. Although the lakeside settlements were still considered to be bathing resorts, the towns around the Lake offered many choices for recreation. The deteriorating state of the shore also played a role in the decline of camping tourism.

The first years of the $21^{\text {st }}$ century indicate a significant downturn in the tourism of Lake Velence.

Between 2000 and 2001 the number of guest nights lessened in Gárdony and Velence (Figure 4). This phenomenon reached its lows in 2008 and 2009, possibly partly because of the recession in the World's economy. The renewed and enlarged Agárd Thermal Spa opened its

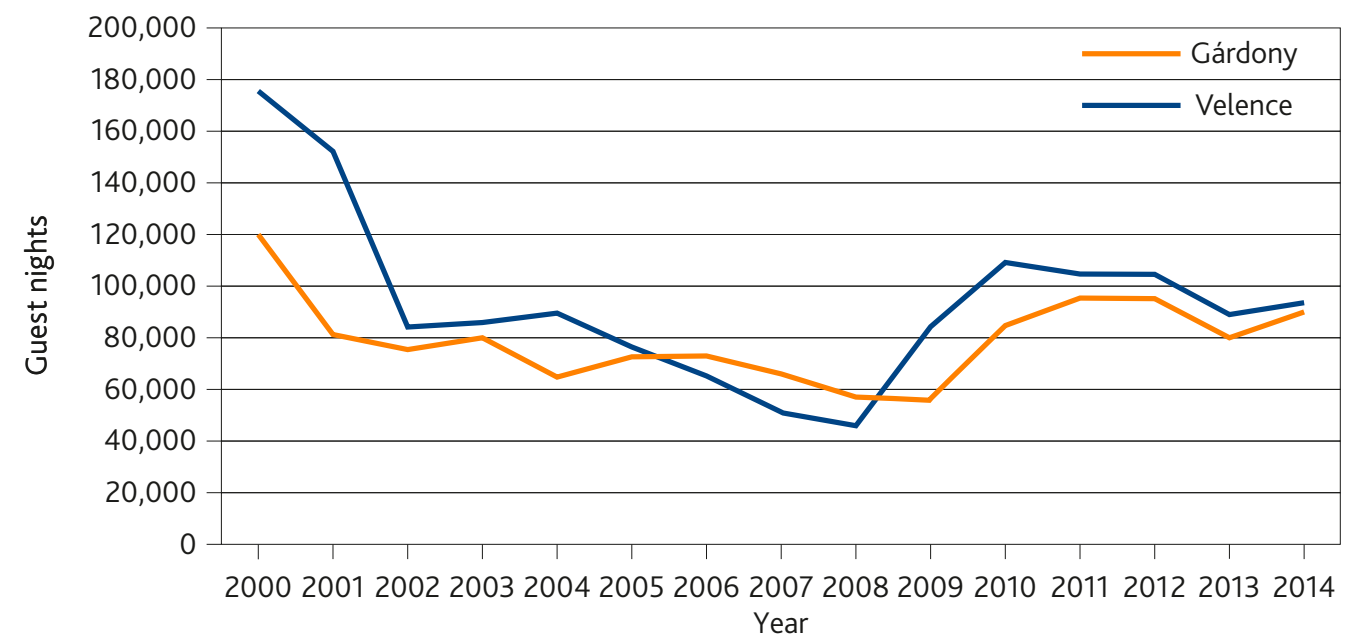

Figure 4: The guest nights of Gárdony and Velence from 2000 to 2014

Source: private editing by SSD data (www.teir.hu) 
gates again in 2005 - supported by the Széchenyi Plan. A new indoor wellness department was added to this spa in 2008 (Vitek, 2009). The next years brought an increase in the tourism palette, which was consciously widened. The number of guest nights in the Hotel Vital Nautis and the Velence Resort\&Spa show this development.

In $201173,5 \%$ of the hotel guests (16015 people) stayed in wellness hotels in Gárdony. $84.66 \%$ of the hotel guests (31847 people), that stayed in Velence chose Hotel Velence Resort\&Spa (SSD). „Wellness facilities and programmes became a worldwide tourist attraction during the last decade of the $2 \mathrm{O}^{\text {th }}$ century and this trend shows no sign of abating, with excellent prospects for continued growth in the future" (Erfurt Cooper - Cooper, 2009, 1).

The new bicycle road, and the Velence-Lake Gate project (which met a lot of difficulties), the Velence promenade and the free beach lure numerous guests to Lake Velence, although their number cannot be seen by the guest nights. This is because of the good transport system. The one-day visitors visit typically Gárdony and Velence.

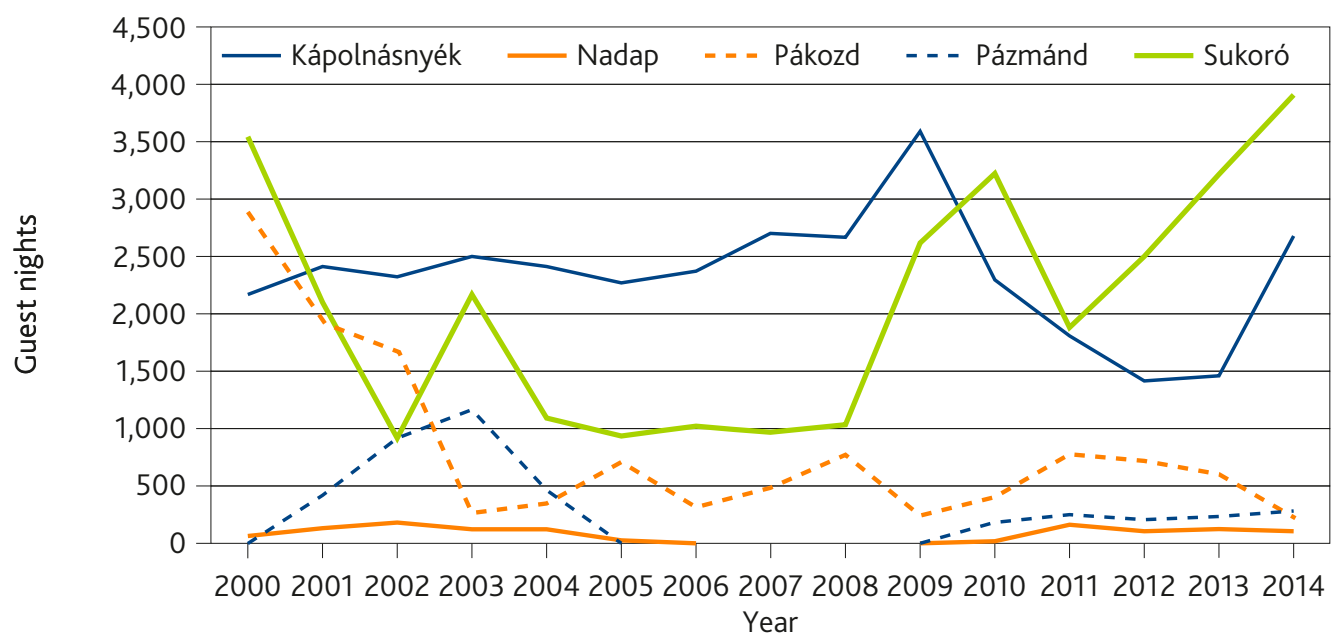

Figure 5: The guest nights of Kápolnásnyék, Nadap, Pákozd, Pázmánd and Sukoró from 2000 to 2014 Source: private editing by SSD data (www.teir.hu)

In 2009, the busiest year in Kápolnásnyék (virtually connected to Velence), 3585 guest nights were counted (Figure 5). This number is well below the amount of guest nights in Velence (84559) and Gárdony (55693), although in these towns the year of 2009 was not the best. In the tourism of Nadap and Pázmánd the lack of accommodation was the problem. Between 2006 and 2011 in Nadap and between 2005 and 2010 in Pázmánd there was not a single commercial or private type of accommodation. The number of guest nights decreased between 2000 and 2014 from 2901 to 220 . This result shows the need of tourism development.

In the $2 \mathrm{O}^{\text {th }}$ century the bathing town character was typical of the Lake, as the most important attraction. Its beaches and weekend houses were popular. At the end of the first decade of the $21^{\text {st }}$ century the emphasis was on thermal and wellness services along with some extras, like local gastronomy. The Sport Beach, the Agárd Thermal Spa, the Hotel Vital Nautis, the Velence Resort\&Spa, the Velence promenade, the Agárd Pálinka Brewery, L. László Simon's Wine House and the Pázmánd Borárium unquestionably determine the tourism of Lake Velence. Events making local products known and involving the tasting of gastronomic specialities form a direct connection between the tourism and agricultural sectors (Cloke, 2007). 
Besides the local governments, several associations deal with tourism and economy development in the Lake Velence area. According to specialist literature the advantage of the tourism destination development (TDM) concept is that stakeholders could play a role in the planning and implementation of development concepts (Virág, 2013). Gárdony and Velence have their own TDM body, the Okos Régió Klaszter (Clever Region Cluster) aims to work on a „local brand” and international economic connections. „Since most of the tourism organisations are small and do not have an agenda for innovation, policies ought to be designed in close association with research centres. Also, they should be supported with clear management indicators, so they can be scrutinised and so that the public will better understand and support them" (Costa et al., 2013).

\section{Conclusion}

On the basis of specialist literature, archive sources and statistical data it can be stated that Lake Velence's becoming a tourism destination in the first half of the 2oth century induced a chain reaction which had an influence on all areas of life. Thus, the development of this branch should not be neglected in the future either. The historical examination shows that the development of Lake Velence region was in the minds of decision makers in earlier centuries too. The historical overview of the Lake and its surroundings raises the question how fundamental structure can be developed in the region. Developments in transport cannot make a settlement successful alone, as seen in case of Gárdony and Velence. Without the initiations of the locals, coordinated tourism development of the Lake Velence Organizational Committee would not have been successful in the 60 of the $20^{\text {th }}$ century.

As a result of the present research, it can be said that besides the improvement of water quality, tourism development at Lake Velence focused on mostly the formation and widening of tourism infrastructure and suprastructure. The developments were concentrated on mainly Gárdony and Velence, so the infrastructural and economic differences became fairly big among the settlements of the Lake. The towns on the northern shore could relieve Gárdony and Velence in the main tourism season because the basic services and facilities were not provided. Consequently, only tourism investments in Lake Velence settlements cannot be ensured efficiently. Moreover, a complex regional development concept is required, which - along with the other economic sectors - means advancement by system approach.

Despite the significant developments from the 1960s, Lake Velence was visited mostly only for daily bathing due to the nearness of Budapest and Székesfehérvár and the continuous improvement of transport. Its advantageous transport-geographical state made Lake Velence primarily to be "the bathing lake of Budapest" at the end of the 1980s, even if the area was able to generate domestic and foreign tourism turnover only to a smaller extent.

As a result of the settlement structure, different parts of the towns got their own image. These differences and individual features should be considered when elaborating development strategies. Keeping functions and characteristics of different settlements to the fore, this principle refers to the settlements and background villages of the Lake, even if the central-periphery conditions make it difficult to develop the region. A growing number of inhabitants here commute to Budapest or to Székesfehérvár and this is becoming an everyday routine. It is not a new phenomenon that the capital has a widening agglomeration. Its potential social, economic and structural effects need further research.

Treating Lake Velence-Vértes as a common development area raises a number of dilemmas. In this region the drainage area means the basic principle of boundaries. Settlements at Lake 
Velence and the Vértes Hills have completely different demographic trends, historical background, different transport system and features and thus a different economic structure. The directing principle should be the agglomeration question in connection with the operation of settlements, rather than the drainage area. Further problems are that although the lakeside resorts are easy to access, the transport is not sufficient as for the background villages. Zámoly and Pátka can be reached only from Székesfehérvár, but the transport between the other settlements is also problematic. The geographical distance also makes it difficult to connect the Vértes settlements to the tourism system of Lake Velence.

Population growth can be monitored due to the developments in transport, infrastructure, the stronger tourism function, and the daily commuting possibilities to Budapest and Székesfehérvár. This strong development causes, however, a number of problems concerning the Lake: some settlements are hardly capable to fulfill even secondary tasks, cannot keep space with the growing demands. The settlements on the northern shore could not ease the crowded southern shore in the peak season because their capacity and infrastructure are not satisfactory.

Lately there have been examples of successful projects, like the bicycle road, but most of them have been individual results and they have been carried out without the mutual development of the settlements. The above-mentioned facts show that the settlements at the Lake Velence have to wait for the breakthrough.

All in all, we can state that the settlements of Lake Velence and Gárdony township can be marketable only with a pre-planned, long-term concept, with a product range of sustainable

tourism and economy, and, last but not least, with an association which can coordinate different economic branches.

\section{References}

Ambrus, L.L., Simon, L., Lukács, L. 2005. Sweet grape, fiery wine. Wine culture of Lake Velence area. Ráció Kiadó-Velencei-tó Környékéért Alapítvány, Budapest-Pázmánd, 372 pp. (in Hungarian)

AFC, 1930. Archive of Fejér County (Fejér Megyei Levéltár) FML IV. B 417/c XVII. k. Goverment of Communities. 6. d. 461. t. Gárdony. 7159. sz. 16.07.1930 (in Hungarian)

AFC, 1971. Archive of Fejér County (Fejér Megyei Levéltár) VIB 9. D. 1. Development Program at Lake Velence. (in Hungarian)

Aubert, A. 2011. The questions of regional tourism. In: Dávid, L. (ed.) The touristic regions of Hungary. Pécsi Tudományegyetem, Pécs, 28-40. (in Hungarian)

Beluszky, P. 2003. Settlement geography of Hungary. Dialóg Campus Kiadó, Budapest-Pécs, 568 pp. (in Hungarian)

Beluszky, P., Győri, R. 2006. This Village is a Town. Tér és Társadalom 2, 65-81 pp. (in Hungarian with English summary)

Beluszky, P., Sikos, T.T. 2007. Changing Villages in Hungary - Spatial distributions of settlements. MTA Társadalomkutató Központ, Budapest, 459 pp. (in Hungarian)

BStU 1986. The Federal Commissioner for the Records of the State Security Service of the former GDR. Archiv der Zentralstelle MfS HA VI Nr. 44. Hauptabteilung VI Bereich Auslandstourismus. Berlin 29. Mai 1986 Berichterstattung zur Auswertung der Beratungen mit den Bruderorganen der CSSR, VRB und UVR zur Sicherung des Tourismusverkehrs von Bürgern der DDR in diese Länder. 14 (BStU 210). (in German) 
Boór, F. (ed.) 1970. Development of Fejér county in 25 years. Data from from the changes in economy and society after WW2. Fejér megyei Nyomdaipari Vállalat, Székesfehérvár, 100 pp. (in Hungarian)

Boromisza, Zs. 2012. The landscape-change of the shore at Lake Velence. Tájvédelmi füzetek 1, 2, 89-99. (in Hungarian)

Costa, C., Panyik, E., Buhalis, D. 2013. Towards a Conceptual Framework: An introduction. In. Costa C., Panyik E., Buhalis D. Trends in European Tourism Planning and Organisation. Channel View Publications. Bristol-Buffalo-Toronto, 1-12.

Cloke, P. 2007. Creativity and tourism in rural environments. In. Richards, G. - Wilson, J. (ed.) Tourism, Creativity and Development. Routledge, London-New York. 37-47.

Erdős, F., Hári, G., Kelemen, K. 2001. Pákozd. Száz magyar falu könyvesháza Kht., Budapest, 188 pp. (in Hungarian)

Erfurt-Cooper, P., Cooper, M. 2009. Health and Wellness Tourism: Spas and Hot Springs. Channel View Publications. Bristol - Buffalo - Toronto. 361 pp.

Formadi, K., Mayer, P., Pénzes, E. 2017. Geography of Tourism in Hungary. In. Widawski K., Wyrzykowski J. The Geography of Tourism of Central and Eastern European Countries. Springer, Cham 189-233.

Huba, L. 1966. Budapest-Velencei-tó-Székesfehérvár. Panoráma, Budapest, 131 pp. (in Hungarian) HCSO (Hungarian Central Statistical Office) 1967. Statistical Yearbook of Fejér county, 1966. Statisztikai Kiadó Vállalat, Budapest, 315 pp. (in Hungarian)

HNR, 1936. Hungarian National Review, Budapest, 1936. 11. 18. 18(264) 70.

HRDUP 1987. Hungarian Regional Development and Urban Planning non-profit association (VÁTI) Concept of the central development program and regional developing plan. VÁTI, Budapest, 109 pp. (in Hungarian)

HRDUP 1986. Hungarian Regional Development and Urban Planning non-profit association (VÁTI) The regional development plan of the Lake Velence region. VÁTI, Budapest, 49 pp. (in Hungarian)

HRDUP 1980. Hungarian Regional Development and Urban Planning non-profit association (VÁTI) Urban planning and city building concept of Lake Velence region: Gárdony, Pákozd, Velence, Kápolnásnyék, Sukoró, Nadap, Pázmánd, Vereb, Lovasberény, Pátka. VÂTI, Budapest, 290 pp. (in Hungarian)

HSI 1938. Hungarian Statistics Issues. Magyar Statisztikai Közlemények. Communique Accomodation of Hungarian Resorts in 1937. (ed.) Magyar Királyi Központi Statisztikai Hivatal. Stephaneum Nyomda Részvénytársaság, Budapest (in Hungarian)

Kupi, L. 20oo. The history of Kápolnásnyék. Kápolnásnyék Önkormányzata, Kápolnásnyék, 176 pp. (in Hungarian)

Kupi, L. 2004. The history of Velence. Velence Önkormányzata-Kornétás, Velence-Budapest, 222 pp. (in Hungarian)

Lengyel, M. 2004. The general theory of tourism. Kereskedelmi és Idegenforgalmi Továbbképző Kft., Budapest, 524 pp. (in Hungarian)

Mason, P. 2003. Tourism Impacts, Planning and Management. Butterworth-Heinamann, Oxford, 195 pp. (in English)

Nagy, L. 2012. The Lake Velence in view of tourism development. In: The tourism of culture: the culture of tourism. Aubert, A., Gyuricza, L., Huszti, Zs. (ed.) IDResearch Kft., Pécs, 277290. (in Hungarian)

Polgár, I. 1914. Lake Velence. Economic study. Debreczenyi István Könyvnyomdája, Székesfehérvár, 23 pp. (in Hungarian) 
Pupos, T. 2007. Project Management, the importance of its applying and its characteristics. In: Cser J., Tóth T. (ed.) Information on Area and Project Planning. Debreceni Egyetem Agrárés Műszaki Tudományok Centruma, Debrecen, pp. 69-129. (in Hungarian)

Rehák, G. 2011. The politics of tourism in Hungary focusing of the first decade of the Kádár era. Ph.D. Thesis. Debreceni Egyetem, Debrecen, (in Hungarian with English summary)

Ruzsányi, T. 2005. The strategic planning. In. Nagy B. The settlement, the built world. B+V Lapés Könyvkiadó Kft., Budapest, pp. 145-168. (in Hungarian)

Sédi, K. 1944. Lake Velence. Velencei-tavi Országos Szövetség, Budapest, 110 pp. (in Hungarian)

Szauer, R. 1964. Camping in Hungary. Sport, Budapest, 208 pp. (in Hungarian)

Tamáska, M. 2006. Inheritance sociological examination of traditional and modern dwelling houses. Szociológiai Szemle 4, 36-62. (in Hungarian)

Virág, Á. 2013. Cooperation to archieve successful tourism. Visegrad Journal on Bioeconomy and Sustainable Development 2, 68-71.

Vitek, G. 2009. Gárdony. History of Agárd, Dinnyés és Gárdony from the beginnings to present times. Gárdony Város Önkormányzata, Dinnyés-Gárdony, 326 pp. (in Hungarian)

Votisky, A. 1934. The problems of Lake Velence. Bethlen Gábor Irodalmi és Nyomdai Rt. Budapest 26 pp. (in Hungarian)

Záhonyi, F. 1964. Paying guest service, the campsites, and motels as the sources of accomodation capacity. Idegenforgalom 23-24, 20-21. (in Hungarian)

SSD, System of Settlement Data. (TeIR) Information system of settlement development. http:// www.teir.hu (downloaded: 17.12.2016)

HCSO, Hungarian Central Statistical Office. http://www.ksh.hu (downloaded: 19. 12. 2016) 